\title{
Restoring the Kingdom of the Mind: Trans-realism and Transgressing Aesthetic Boundaries in Ben Okri's Fiction
}

\section{Elizabeth Syrkin}

\section{(2) OpenEdition Journals}

Electronic version

URL: https://journals.openedition.org/ces/5342

DOI: $10.4000 /$ ces. 5342

ISSN: 2534-6695

\section{Publisher}

SEPC (Société d'études des pays du Commonwealth)

\section{Printed version}

Date of publication: 1 April 2013

Number of pages: $45-55$

ISSN: 2270-0633

\section{Electronic reference}

Elizabeth Syrkin, "Restoring the Kingdom of the Mind: Trans-realism and Transgressing Aesthetic Boundaries in Ben Okri's Fiction", Commonwealth Essays and Studies [Online], 35.2 | 2013, Online since 17 April 2021, connection on 23 July 2021. URL: http://journals.openedition.org/ces/5342 ; DOI: https://doi.org/10.4000/ces.5342

\section{(c)}

Commonwealth Essays and Studies is licensed under a Licence Creative Commons Attribution - Pas d'Utilisation Commerciale - Pas de Modification 4.0 International. 


\section{Restoring the Kingdom of the Mind: Trans-realism and Transgressing Aesthetic Boundaries in Ben Okri's Fiction}

This paper reads Ben Okri's The Famished Road in the light of his lesser-known novel Astonishing the Gods, which illuminates his aesthetic aspirations, particularly his desire to alter the way we perceive and interact with the world. Okri transgresses aesthetic boundaries through what he terms "trans-realism" - a form of writing that he says is both "inside and outside realism," and which critics have variously called magical, spiritual, sacred, and animist realism. I consider how Okri's approach engages questions of perception and vision, and how it consistently transcends rigid categorisations.

In his poem "Lament of the Images," which opens his 1992 collection An African Elegy, Nigerian author Ben Okri writes:

And the spirits

Hunger

For our touch

Our contact. (12)

Okri's poem introduces a seemingly invisible realm that cries out to be experienced, and emphasises the layering of disparate dimensions and realities that is a marker of his aesthetic. His answer to these spirits' call through their entry into the pages of his novels has led critics to assign his writing to categories that engage forms of non-realist representation: terms like spiritual, animist, magical, and sacred realism have variously occupied analyses of his Booker Prize-winning The Famished Road, for example, which place his work within postmodernist and postcolonial frames. ${ }^{1}$ Okri has repeatedly resisted these attempts to label his writing, suggesting in his collection of essays $A W$ ay of Being Free that neat categorisations have a tendency to "conceal" and "reduce" reality (88). Indeed, attempts to absorb Okri's writing within single, restrictive classifications deny aspects of his fiction that exceed the signification of the various monikers assigned to it. As Robert Fraser aptly states, Okri's writing instead represents "a form in the making" (66). Okri uses the word "trans-realism" to refer to his ambition to transgress aesthetic boundaries in order to capture the realms and forces that, to use a recurrent motif in his writing, blend and bleed into each other like the colours from a paintbrush. As he explains, this form of writing is both "inside and outside realism" because Okri believes "realism is too limited a mode to talk about reality" (qtd. in Fulford 251). The prefix "trans" points towards the existence of dimensions of reality beyond traditional realism and suggests it is the writer's task to "catch as many layers of reality" as possible, as Okri explains in another interview (Wilkinson 82). He opposes the porosity of trans-realism to the perpetual need to assign a label and fit texts neatly into its parameters. Therefore, rather than attempting a strictly "trans-realist" reading of Okri's fiction, I will consider how and to what effect Okri's writing transgresses the limitations of realism in an attempt to subvert aesthetic boundaries.

1. See Appiah on Okri's spiritual realism, Garuba on his animist realism, Mathuray on his sacred realism, Cooper on his magical realism (as a subcategory of postmodernism), and Ogunsanwo for a postcolonial perspective. 
Okri provides direction for such a reading when he elaborates on his aesthetic agenda in a 1994 radio interview:

It's a new yearning [...] that is slowly occupying the old tyranny of the mean description of reality. We are now becoming increasingly dissatisfied with the linear, scientific, imprisoned, tight, mean-spirited [...] description of reality and human beings. We want more because we sense that there is more in us [...]. We need ritual, initiation, transcendence of consciousness [...]. These are things that are always part of all societies. It's just we went ahead and forgot. And I think we are paying a terrible price for it, and it's only the psychiatrists who benefit. The thing is that it's time that we started healing the human spirit by giving back to it its full, rich, hidden dimensions. And that is all I am trying to do in my fiction - to restore the kingdom. (qtd. in Ogunsanwo 40)

With this Okri addresses his move from realist representation in his earliest fiction like Flowers and Shadows (1980) to the increasingly magical and abstract experimentation characteristic of the trilogy gathering The Famished Road (1991), Songs of Enchantment (1993) and Infinite Riches (1998). Critics have observed a similar movement in the novels of other African authors, including Chinua Achebe, Ngũgĩ wa Thiong'o, and Ayi Kwei Armah, who have increasingly developed alternative forms that Ato Quayson calls "mythopoeic experimentation" (Strategic 164). Quayson attributes this shift to rising disillusionment with independence revolutions and deteriorating conditions in Africa: "The state of corruption made it impossible to write about events using the same rationalism of prevailing protocols of representation," so that the "radicalisation of narrative form" in texts like The Famished Road renders "the acute sense of bewilderment at the incoherence of the socio-political domain" ("Esoteric" 156). ${ }^{2}$ Furthermore, this shift can be read as a form of subversion within and as narrative form, amounting to a rejection of "the legitimizing narrative archetypes of Western culture and its dominant ideology," (Ogunsanwo 41) that in turn perpetuate the "tyranny" of Western influence on the continent Okri describes in the interview above.

Okri's aesthetic acts within while simultaneously exceeding such a conventional (post)colonial framework. As he explains in an interview, too much emphasis has been placed on the "effect of colonialism on our consciousness" at the expense of "our own aesthetic frames" (Wilkinson 86). Okri sees reality as denser than the "mean description" found in realism, which he describes in the 1994 interview as a "linear, scientific, imprisoned" aesthetic unable to convey the depth of reality because it is limited to a transcription of how reality is directly experienced by the senses, overlooking what "is more in us" (qtd. in Ogunsanwo 40). As Okri points out, the disparate realms in The Famished Road are not metaphoric constructs, but rather a part of the "real" yet unrepresented in the society he depicts: "I am looking at the world in The Famished Road from the inside of the African world view [...] This is just the way the world is seen: the dead are not really dead, the ancestors are still part of the living community and there are innumerable gradations of reality" (Ross 337-8). Eliminating these dimensions of the real, Okri believes, has a stultifying effect that presents itself as increasing psychological distress, and is reminiscent of the alienation and spiritual numbness often associated with modernisation and the rise of global capitalism. "Before I left Nigeria," Okri recalls for instance, "people spoke about the spirits and when I go back that's crushed too

2. See also Gaylard 4, 30-2, 59 . 
and no one's talking about them anymore. So everywhere there is this extra dimension of things that has slowly been murdered in the minds of people" (qtd. in Fulford 254).

Central to Okri's fiction is "healing the human spirit" by reintegrating these absent layers into experience in order to capture the "full, rich, hidden dimensions" of reality, a task for which a standard realist aesthetic, as he understands and describes it in the 1994 radio interview above, is largely inadequate (qtd. in Ogunsanwo 40). His trans-realist approach therefore foregrounds perception, consciousness, and modes of seeing, reflecting Okri's repeated assertion that the way people "perceive the world" shapes the ways in which it affects them and is in turn affected by them: "It's the invisible things that shape the visible things" (Wilkinson 88). Incorporating these invisible realms allows his fiction to question the habitual and ingrained discourses and ideological frameworks that underlie society, and as we will see with The Famished Road, to awaken the mind to the existence of new perspectives, destabilising a seemingly entrenched powerlessness.

This paper approaches Okri's most famous novel, The Famished Road, in the light of his 1995 novel Astonishing the Gods, published between the second and third instalment of the trilogy, and arguably the most sustained manifestation of this trans-realist experimentation in his fiction. Taking direction from Robert Fraser, who argues that Astonishing the Gods clarifies Okri's crossing of aesthetic boundaries in his trilogy (82), I contend that a closer look at this lesser-known and complex novel indeed sheds light on the intricate workings of The Famished Road, illuminating the operations of perception and consciousness that permeate his writing.

\section{Astonishing the Gods}

Since its publication in 1995, a number of critics have described Astonishing the Gods as vague, pompous, obscure, and even meaningless. ${ }^{3}$ One critic argues that its amorphous plot fails to provide the same level of experimental energy and political engagement as The Famished Road (Bennett 368). This last contention overlooks the possibility of reading Astonishing the Gods as a novel that bends the boundaries of political engagement in fiction by creating a space for the mind itself to become physically present on the page. Okri uses what may be termed "psychic realism," a term pioneered by Jeanne Delbaere-Garant to describe a form that makes physically manifest what takes place inside the psyche (255). By portraying and rendering visible on the page otherwise invisible realities - thoughts, dreams, abstract concepts - Okri redefines reality to include ontological experiences that feel real as we experience the world. Foregrounding the mind of an individual grappling with abstract notions, Okri fashions a utopia of the mind, in which, rather than seeking to reconfigure society as a whole, he depicts how a narrative consciousness learns to perceive in a new and trans-realist way: to walk as the novel's protagonist does, "through realms, through dimensions" (49).

The entire plot of Astonishing the Gods centers on this consciousness as it grapples with divergent concepts, so that the "vagueness" (Wright 331) noted by some critics can instead be interpreted as a mind's struggle with not quite fully formed ideas in a process of self-perfection. Astonishing the Gods introduces a nameless protagonist who is born invisible, an invisibility he notices after he reads about his likewise invisible people. This discovery prompts him to go on a quest for visibility, which brings him 
to a mysterious island whose inhabitants are invisible to him, just as he is to them. The novel recounts the protagonist's stay on this island as he is instructed by three separate guides in the ways of what appears to be an ideal society. The spatial location of this island is consistently reaffirmed as the mind of a subject working through abstract notions: the main merchandise of the city, traded at the marketplace, are "intuitions, prophecies, paradoxes, riddles, enigmas, visions, and dreams," (74) banks use thoughts of well-being, wealth, and serenity as their currency (69), and the inhabitants are dedicated to the self-declared "perfection of the spirit" (67). Having sought the secret of visibility, the protagonist instead feels himself "becoming more insubstantial, less real" as the "heaviest and least important parts of him," his physical body, "dissolv[e] in the effulgent lights" (10). His journey ends in the palace of the main square within which he undergoes questioning by a council of Invisibles and attains the "invisibility of the blessed" (159). In order to address the meaning of this transformation, which in many ways is a culmination of Okri's trans-realist ambition as it explicates the shift in perception he hopes to inspire through his fiction, I will briefly consider Okri's language, with a particular emphasis on his engagement of the senses and his use of paradox.

Okri's use of verbs like "shimmered" (122) and "quivering" (6) to describe the physical landscape of the city suggests a world continuously on the brink of transformation. As the protagonist enters the city with his first guide, "quite imperceptibly, things began to change": "A house of justice became a mood of green. The fragrance of roses turned into the statues of five Africans along the street" (40). These crossings into a kind of fluctuating reality are underscored by the use of synaesthesia - the interaction and merging of the senses during the moment of perception ${ }^{4}-$ as Okri infuses perceptions with colours and adds alternate dimensionality to objects, sounds, and moods. The protagonist hears (and sees) "silver melodies" (39) and observes the "violet perfection of the streets [...] shaped purely by music" (37). Capturing the vibrating cadences underlying the observable world, these constant transformations defamiliarise the city and prevent both the reader and the protagonist from understanding and categorising it too easily. A special emphasis is placed on alertness, on being fully conscious of experience - a need forced on the protagonist as he is made to return to parts of the city he had already seen, but "hadn't been aware of" (43). His guide explains that one must constantly "relearn" in this city because "[t]oo much forgetting led to our great suffering" (17). People who sleep through their experiences, he explains, must "undergo them for as many times as it takes to wake them up and make them feel the uniqueness $[\ldots]$ of their experiences for the first time" (47). This active engagement and acute responsiveness is a marker of trans-realist perception and provides a vital framework for deciphering the form and message of The Famished Road.

Okri further explores the multi-dimensional effect of language through his use of paradox. Paradoxical images abound, with visions of women "singing silently" within mirrors (10), or of a lamp "whose glow created [...] a deeper darkness" (85). In recurring confrontations with the city's inhabitants, dialogue with the protagonist develops through paradox. In this city, a "dwarf-like figure" explains that "if you look for something you won't find it," because you "have to find things first before you look for them" (103). Such paradoxical statements cause the protagonist to ponder the under-

4. On synaesthesia in literature, also known as intersense analogy, see O’Malley 392-3. 
lying meaning of concepts like ownership. "If you're not aware of something, you never had it in the first place," the figure continues, "You didn't give it life. And so it wasn't real for you. In this place things lose their reality if you are not aware of them" (103-4). The figure's statement expands on the guide's persistent claim that engagement and receptiveness can combat the suffering that emerges out of forgetting (17). Resolving a paradox to arrive at the deeper truth it illuminates requires the ability to engage all the meanings it encompasses and to abjure "looking for solid ground, for certainties," (104) recognising these as mere mirages that obscure the shifting nature of reality.

The novel culminates in the protagonist's paradoxical attainment: "he who had left home in search of the secret of visibility [...] found a higher invisibility, the invisibility of the blessed" (159). Its prominent position throughout the novel marks invisibility as vital for understanding trans-realist perception, especially in view of Okri's contention that the visible is shaped by that which cannot be seen. Conceived in the opening pages of the book as simply another dimension when the protagonist finds that because of their shared invisibility, his mother could see him, invisibility accrues political resonance when the protagonist "searche[s] for himself and his people in all the history books he read and discover[s] to his youthful astonishment that he didn't exist" (3). His status as a colonial subject, it seems, marks him as "invisible" in the history books of the West. While framing it as marginalisation, Astonishing the Gods nevertheless complicates a standard postcolonial reading of invisibility by making the protagonist's greatest achievement the attainment of a deeper invisibility. On the one hand, this can be read as the unique perspective allotted an individual who through his own marginalisation, his knowledge that what is seen is never the whole story, is able to understand the limits of realism and categorisation. Yet, on the other hand, invisibility is presented as the goal of the evolution of the mind throughout the protagonist's journey, rather than as an initial state - a process that entails transcending a division between the visible and invisible. The protagonist's encounter with the council of Invisibles illuminates the nuances at work in this conception of the unseen.

Standing in a great hall filled with people he cannot see, the protagonist feels they are "in a separate realm, a hidden dimension" (136). In a moment of willed self-transformation, he realises that in order to see them, he must "imagine himself blind. With his eyes shut, he made an astonishing discovery. They became real [...] And so, blind among the empty chairs, he suddenly could see" (136). Seeing reality here involves a willingness to see differently in the manner of experiencing paradox or synaesthesia, of being attuned to unseen layers of reality, thereby dissolving the boundary between the visible and the invisible. The ceremony begins with speeches by three masters. As the first gets up to speak, his "words began to alter the hall," transporting the protagonist to a "different place" in which he feels himself "being raised up, being changed" (137). Endowed with a transformative potential, language continues to transport with the words of the second master: "he realised that he was somewhere else, in an eternal room of meditation, amongst the most magical thoughts and enchanted silences in the world. The thoughts converged there from all realms. And each thought had infinite possibilities" (139). The text peels away at the layers making up these thoughts, which originate from "stones and seraphs, from trees and birds, from beings who dwelled in the air [...] from human beings all over the world" (140). A shift in perception, caused by language here, entails a merging of realms that indiscriminately endows everything 
with spiritual essence. As the third master's speech "filled the hall with music," and as the music brings forth visions of "beautiful things flowering from great suffering," of "glittering ideas in sound," (142) the protagonist feels "that he had become smaller and therefore greater, that he had become hidden and therefore could learn to see" (143). Open to being transported and inspired, his mind enters this realm of ever-occurring paradox, and it is out of such contradictions, the paradoxical speaking "silence of all the Invisibles," that the truths of the island emerge:

We measure time differently, not by the passing of moments or hours, but by lovely deeds, creative accomplishments, beautiful transformations [...]. Our highest acts of creativity are in the empty spaces, in the air, in dreams, in unseen realms. There we have our cities, our castles, our greatest books, our great music, our art, science. [...] We are learning to be masters of the art of transcending all boundaries. We are learning to go beyond the illusion that is illusion. (147-8)

The silent voice locates the source of this society's accomplishments - its art, its science, its architecture, its literature - within a realm only accessible to a trans-realist perception, one that transcends the limitations of sight and emerges out of the unseen, and one whose attainment is a continuous process consciously undertaken. In contrast with the visible and purely physical realm in which, in the words of the dwarf-like figure, "people have names $[\ldots]$ and where there are a thousand useful and beautiful illusions," (108) this dimension resists the illusion of concrete physicality and definitive meaning.

Inspired by this, the protagonist speaks out of a "new consciousness" as he is questioned by an angelic voice (154). Asked about the purpose of invisibility, he answers in emphatic capitals, "PERFECTION," (155) underscoring the ability to "perfect" a mode of thinking and seeing by striving to engage other realms. Asked what the dream of the Invisibles is, he responds: "TO CREATE THE FIRST UNIVERSAL CIVILISATION OF JUSTICE AND LOVE” (155). With this answer Astonishing the Gods moves from the abstract creation of a utopia of the mind to acknowledging the role to be played by such transformation within the world through the creation of a particular type of society and approach to being in the world. Having remade an inner reality, embodied in this attainment of invisibility, and with it an engaged, all-encompassing, trans-realist vision, the novel frames such transformation as a quest to remake the world. Mirroring this need to, in Dad's words, "look at the world with new eyes" (498) in order to institute change, The Famished Road already explores the questions raised by Astonishing the Gods, staging a battle "for the future of our country [...] in the spirit spaces" (495).

\section{The Famished Road}

The Famished Road chronicles the adventures of Azaro, an abiku child reborn in repetitive cycles within the "world of the Living," (3) only to die and return to the spirit world. ${ }^{5}$ Yet Azaro makes the deliberate choice to stay, and the narrative details his spirit companions' repeated attempts to retrieve him, focusing especially on Azaro's episodic wandering in the forest and on roads that, in his description, lead "towards home and then away from it, without end, with too many signs, and no directions" (115). The novel's iterative plot and tortuous prose mirror these winding and endless roads, causing some

5. On the abiku in Yoruba mythology see Quayson, Strategic 10-1, and on other literary treatments of the abiku see 123-4; on Okri's rewriting of the abiku myth, see Ogunsanwo 47. 
critics to disparage its tedious, oppressive cyclicality: "Not much happens. What does transpire seems familiar and repetitive, as though one is living through many versions of the same dream or nightmare" (Cooper 68). Others note the oscillation between "realistic" and "esoteric" or mythic episodes, ${ }^{6}$ overlooking Okri's stated desire to describe the way the world is seen from a perspective that rejects such distinctions. Rather than setting the reader as the standard by which reality is measured, I follow Fraser's reading by taking "Azaro's viewpoint with absolute seriousness," placing the "numinous presences" in the text on the same plane as the "ordinary" (81). Azaro frames his choice to stay as a desire to stop "coming and going," to stop remaining forever "inbetween" (5). He highlights the porosity of the boundary between worlds as he combats "in-betweenness" by superimposing the vision of one world onto the perception of the other, fashioning a trans-realist perspective in which, in Okri's words, life is lived "simultaneously at different levels of consciousness" (Wilkinson 83). The novel traces Azaro's growth into that vision as he appropriates the spiritual and unseen into his everyday being. Reading Azaro's oscillating journeys through the lens found in Astonishing the Gods helps untangle the way this labyrinthine and iterative narrative engenders the trans-realist transformation in perception found in the quest for invisibility.

Azaro is constantly awakened to sensory impressions that he experiences in a deeply physical way throughout his wandering, described in passages reminiscent of Astonishing the Gods: "The blue shadows of green trees blinded me. [...] Flowers which I didn't see scented the dense and tender breeze. I listened to the fluted sound of birds, the murmurings of a distant stream" (242). Okri infuses Azaro's world with colour, describing "blue memories" and "silver glances," (182) or the fragrance of a "yellow impassivity" (290). Awakened and engaged, he continually enters successive realms, emerging in one only to pass into another on the next page (241-2). On one striking occasion, Azaro is forcefully torn away from such a journey by Mum. Walking on the "dissolving streets" of a perpetually transforming world, listening to the air "full of riddles" as he follows a beautiful woman who draws his spirit "on to fountains of light and lilac music," he is suddenly beckoned by a voice "from a heavier world" (307). As Mum lifts and carries him home,

[t]he air became void of riddles. I heard the last notes of a flute adagio floating across a lake of green mirrors. Mum took me home over the mud and wreckage of the street [...] I smelt the gutters and the rude plaster of the corroded houses. Then all I was left with was a world drowning in poverty. (307-8)

Azaro is transported to a purely physical dimension here - the world of illusion introduced in Astonishing the Gods - and finds it difficult to reconcile his synesthetic perception with the ingrained poverty of his day-to-day life, so that the deeper layers of reality, the sounds and colours and ungrasped meanings of riddles fall away. This journey towards experiencing the world's "full, rich, hidden dimensions" recurs again and again, slowly subsuming Azaro's view of his daily surroundings and heightening his alertness to detail: "My journey into the secret world changed things I saw in the room," turning "tumbles of clothes" into "shawls, undergarments, coloured headties, batik materials" (292). As he later declares: "I looked at the world, I tried to see all that was in it, I embraced all things into my life" (342).

6. See Quayson, Strategic 127, 134. 
Okri frames this transformation as a struggle undertaken within each individual to ascertain how they interact with the world, consistently highlighting the myriad ways in which people perceive it. In one episode, the blind old man forces Azaro to look at the world through his eyes, forcing him to wake "into a nightmare":

When I looked out at the world again, what I saw made me scream. [...] The spaces between things were populated with the most horrifying spirits I have ever seen. They had wounds all over them which dripped pus. When they talked green spit poured from their mouths. (313-4).

The man's infernal vision contrasts radically with the radiant colours and pleasant smells characteristic of Azaro's visions, emphasising the way people project internal realities onto the world, a process explained by one of the guides in Astonishing the Gods: "things are what they are [...] You're lucky if you can see wonderful things. Some people who have been here see only infernal things. What you see is what you are, or what you will become" (11). The world becomes what it is in being perceived as people project both themselves and future potentialities onto it, altering the discourses and meanings assigned to what is seen.

Azaro's trans-realist perception emerges out of a deep sensitivity to all the world's shades in a manner that recalls Astonishing the Gods. In a journey through the spirit world during his hunger strike after a particularly brutal beating at the hands of Dad, for instance, Azaro feels "perpetual astonishment" at the increasingly vivid and constantly changing colours in this world, "colours so dazzling, so full of health and radiance, colours that blurred all distinctions between brightness and darkness, that seemed to occupy the highest octaves of new dreams" (327). In a paradoxical exchange with his three-headed spirit companion that echoes the protagonist's discussions with his guides in Astonishing the Gods, Azaro asks:

"Are we travelling this road to the end?"

"Yes," the spirit said [...].

"But you said the road has no end."

"That's true," said the spirit.

"How can it be true?"

"From a certain point of view the universe seems to be composed of paradoxes. But everything resolves. That is the function of contradiction."

"I don't understand."

"When you can see everything from every imaginable point of view you might begin to understand."

"Can you?"

"No." (327)

Azaro's awareness of the world's wondrous colours and hues is coupled with a paradoxical approach that enfolds and resolves contradictions through their coexistence in the eyes of the beholder. The spirit's use of "when" suggests the attainability of such a vision, but his own inability to see "from every imaginable point of view" marks it as a long and arduous process - one that Okri does not suggest is attained in this first instalment of his trilogy. Instead, the novel and its protagonist consistently reaffirm this quest for a trans-realist perception as a driving force for the novel, with Azaro marvelling at "these paradoxes of things, the eternal changes, the riddle of living while one is alive $[\ldots]$ the challenge of giving birth to one's true self; $[\ldots]$ the possibilities of a new pact with one's spirit; the probability that no injustice lasts for ever" (488). Azaro 
recognises that fostering a vision, and therefore a new self, requires being attuned to life's changes, riddles, and paradoxes, and that such a "pact" with oneself is related to combating the world's injustices. Upon a second reading, then, Azaro's quest for an alternate mode of seeing comes to the fore on the novel's very first page in a rare analytical interjection that explains the spirit children's fear of the "world of the Living": "We feared the heartlessness of human beings, all of whom are born blind, few of whom ever learn to see" (3). The narrator attributes the heartlessness and the all-pervasive, real-world suffering described in The Famished Road - the mundane world of hunger, dirt, and poverty largely absent from Astonishing the Gods - to a lack of vision, so that "restor[ing] the kingdom" in the manner described by Okri entails a self-transformation with significant consequences in the world.

Towards the end of the novel, Azaro describes the war waged by political parties "in the spirit spaces" of the people (495):

Suspicion made it easier for us to be silent. Silence made it easier for us to be more powerless. The forms of dominance grew more colossal in the night spaces. And those of us who were poor $[. .$.$] who didn't see the power of our own hunger [. .$.$] found that$ our dreams became locked out of the freedom of the air. Our yearnings became blocked out of the realms of manifestation. The battles for our destiny raged and we could no longer $[. .$.$] imagine how our lives could be different and better. (496)$

The cycle of powerlessness perpetuates itself and stunts the ability to imagine alternatives even in "dreams" and "night spaces." In The Famished Road, invisibility presents itself as the invisible dimensions and potentialities within the self that are reached in Astonishing the Gods, and which could rupture this cycle of powerlessness. The novel culminates in the recognition of such power in Dad's final speech. In a moment that echoes Astonishing the Gods exactly, Dad explains that in the "empty spaces [...] are cities, invisible civilisations, future histories, everything is HERE. We must look at the world with new eyes. We must look at ourselves differently. We are freer than we think" (498). Dad sees the potential for societal transformation within a new vision that embraces invisible layers of experience, including one's own power in spite of being downtrodden. In the manner of the protagonist's paradoxical realisation in Astonishing the Gods, Dad exclaims: "I am blinded - I am beginning to see" (499). The Famished Road is often criticised for this prophetic ambition, which seemingly fails to address the value and function of an altered perception. Yet I argue that rather than retreating from the real world into disembodied abstractions, Okri engages it more deeply by confronting how discourse structures society and reality. What people perceive informs their thoughts, beliefs, and ambitions, which in turn have a direct impact on political discourse. The power discourse holds over reality is famously illustrated in the overwriting of Okonkwo's story by the District Commissioner in Chinua Achebe's Things Fall Apart (1958), reducing it to a single paragraph in a book entitled: The Pacification of the Primitive Tribes of the Lower Niger (148). The Commissioner's act of erasure, which Achebe forcefully contests through his novel, is akin to the ingrained powerlessness described throughout The Famished Road that Okri battles by constantly testing modes of perception. Okri foregrounds this battle over discourse and representation, exploring the power of language to alter reality the same way it "alter[s] the hall" in Astonishing the Gods (137).

I want to conclude by focusing on Okri's use of photography in the novel, which I suggest embodies such an alternative and trans-realist mode of seeing, endowed as it 
is with the potential to capture unseen layers of reality and awaken people to invisible dimensions within themselves. The group photograph of Azaro's party, for example, juxtaposes the fixed smiles of the gathering with a "cramped, and hungry" reality: a room that appears constructed "out of garbage" and transforms these smiles into the contorted "grimaces" of a "defeated" people (91). Indeed, as Matthew Green argues, the photographer's images "exercise an imaginative power $[. .$.$] highlighting a spiritual$ dimension - the spirit of suffering suffused throughout the novel - that the characters themselves no longer see" (24). A protracted existence amidst dirt, hunger, and poverty has rendered invisible an entire "spiritual dimension" of their suffering, reflecting the nature of their internalised powerlessness described above. The defamiliarising representation of this scene through photography brings this submerged layer to the fore - yet the function of photography is further demonstrated in its ability to alter the process of seeing itself. When Azaro examines the pictures displayed in the photographer's cabinet, pictures of "thugs beating up market women," of "politicians being stoned at a rally, [catching] their panic, their cowardice," (160) he is transformed by these representations. Wandering the road after looking at them, he becomes more attuned to the conditions that surround him, shifting from the usual physical and objective descriptions of what he sees to emotion and analysis:

I was frightened by the feeling that there was no escape from the hard things of this world. Everywhere there was the crudity of wounds, the stark huts, the rusted zinc abodes $[\ldots]$. The sun bared the reality of our lives and everything was so harsh it was a mystery that we could understand and care for one another or for anything at all. (161)

The photographs function here in a manner similar to the synaesthetic and perceptually engaged vision from which Azaro is torn by Mum - they awaken him to the nature of the reality he is carried back to, altering the way he perceives and interacts with the world.

Yet it is photography too that hints at the political power of such representation when a photograph of the neighbourhood's rebellion against the Party of the Rich, which poisoned them with rotten milk, appears in the newspaper: "We were astonished that $[\ldots]$ something that we had done in such a small corner of the great globe, could gain such prominence" (156). Representation and seeing here control discourse as people begin to talk about what is represented, so that when the photographer is driven out and fails to capture a second rebellion a few chapters later, the very ability to recall the event is stifled: "nothing of the events appeared in the newspapers. It was as if the events were never real [...]. We began to think that we had collectively dreamt up the fevers of that night. It wouldn't be the first or the last time" (183). An event is "real" here in so far as it is represented, re-seen, and discussed, recalling the guide's explanation in Astonishing the Gods that one must constantly "relearn" since "suffering" is caused by forgetting (17). This cycle of forgetting is revealed when two hundred pages later, as the Party of the Rich returns with grand slogans, no resistance is shown against those who had poisoned and beaten them: "people had forgotten, and those that hadn't merely shrugged and said that it was all such a long time ago, that things were too complicated for such memories" (387). Photography is endowed here with a political potential, acting as an example of the way in which a trans-realist vision can be accessed and employed.

By moving the reader through the staccato associations made by its child protagonist, its repetitions and cyclicality, its aesthetically engaged and engaging language, The 
Famished Road elaborates a trans-realist perception and approach to writing that can, in Okri's words, "restore the kingdom" of the mind to the dimensions hidden within it. Trans-realism itself morphs into a realism of excess, a hyper-consciousness of the mind that is an essential part of attaining invisibility in Astonishing the Gods. The Famished Road engages the world in an equally complex and inclusive way, exploring the real world functionality of this trans-realist perception by connecting it to the discourses that permeate the world. Endeavouring a socio-political reconstruction from within, Okri's novels participate in a dialogue about literary forms and political realities by presenting a trans-realist aesthetic and vision that, instead of merely transcending boundaries and layers of reality, enfolds these and reflects them back, transformed, merged, and filled with discursive potential.

Elizabeth SYRKIN University of Muenster

\section{Works Cited}

Achebe, Chinua. Things Fall Apart. Oxford: Heinemann, 1958.

ADIL, Alev. "More Narnian than Olympian." Times Literary Supplement 10 Mar. 1995: 23.

Appiah, Anthony K. "Spiritual Realism." The Nation (3-10 August 1992): 146-8.

BenNETT, Robert. "Ben Okri (1959-)." Postcolonial African Writers: A Bio-Bibliographical Critical Sourcebook. Ed. Puspa Naidu Parekr, and Siga Fatima Jagne. Westport: Greenwood, 1998. 364-73.

Cooper, Brenda. Magical Realism in West African Fiction: Seeing with a Third Eye. New York: Routledge, 1998.

Delbaere-Garant, Jeanne. "Psychic Realism, Mythic Realism, Grotesque Realism: Variations on Magic Realism in Contemporary Literature in English." Magical Realism: Theory, History, Community. Ed. Wendy Faris, and Lois Parkinson Zamora. Durham: Duke UP, 1995. 249-63.

Fraser, Robert. Ben Okri: Towards the Invisible City. Tavistock, UK: Northcote, 2002.

Fulford, Sarah. "Ben Okri, the Aesthetic, and the Problem with Theory." Comparative Literature Studies 46.2 (2009): 233-60.

Garuba, Harry. "Ben Okri: Animist Realism and the Famished Genre." The Guardian (Lagos) 13 March 1993: 23.

GAYLARD, Gerald. After Colonialism: African Postmodernism and Magical Realism. Johannesburg: Wits UP, 2005.

GreEN, Matthew. "Dreams of Freedom: Magical Realism and Visionary Materialism in Okri and Blake.” Romanticism 15.1 (2009): 18-32.

Mathuray, Mark. "Sacred Realism: Ben Okri's The Famished Road." On the Sacred in African Literature: Old Gods and New Worlds. Basingstoke: Palgrave Macmillan, 2009. 115-36.

Ogunsanwo, Olatubosun. "Intertextuality and Post-Colonial Literature in Ben Okri's The Famished Road." Research in African Literatures 26.1 (1995): 40-52.

Okri, Ben. The Famished Road. London: Jonathan Cape, 1991.

—. "Lament of the Images." An African Elegy. London: Jonathan Cape, 1992. 9-13.

-. Astonishing the Gods. London: Phoenix, 1995.

-. A Way of Being Free. London: Phoenix, 1997.

O’Malley, Glenn. "Literary Synaesthesia." Journal of Aesthetic and Art Criticism 15.4 (1957): 391-411.

QuaYson, Ato. "Esoteric Webwork as Nervous System: Reading the Fantastic in Ben Okri's Writing." Ed. Abdulrazak GuRnAH. Essays on African Writing II: Contemporary Literature. Oxford: Heinemann, 1995. 144-58.

-. Strategic Transformations in Nigerian Writing: Orality and History in the Work of Rev. Samuel Johnson, Amos Tutuola, Wole Soyinka \& Ben Okri. Oxford: James Currey, 1997.

Ross, Jean. "Contemporary Authors Interview (with Ben Okri)." Contemporary Authors 138. Ed. Donna OlENDORF. Detroit: Gale, 1993: 337-41.

WiLkInson, Jane. Talking with African Writers: Interviews with African Poets, Playwrights and Novelists. London: James Currey, 1992.

Wright, Derek. "Whither Nigerian Fiction? Into the Nineties." The Journal of Modern African Studies 33.2 (1995): 315-32. 